\title{
Early Childhood Care in France: Impediments to the Professionalization of a Little-Institutionalized Feminine Occupation
}

\author{
Sophie Devineau \\ DySoLab Research Center, University of Rouen, Normandy, France \\ Email: sophie.devineau@univ-rouen.fr
}

How to cite this paper: Devineau, S. (2019) Early Childhood Care in France: Impediments to the Professionalization of a Little-Institutionalized Feminine Occupation. Open Journal of Social Sciences, 7, 343-357. https://doi.org/10.4236/jss.2019.710029

Received: September 11, 2019

Accepted: October 22, 2019

Published: October 25, 2019

Copyright $\odot 2019$ by author(s) and Scientific Research Publishing Inc. This work is licensed under the Creative Commons Attribution-NonCommercial International License (CC BY-NC 4.0).

http://creativecommons.org/licenses/by-nc/4.0/

\begin{abstract}
In the early-childhood care sector, the occupation of home-based childcare providers is especially subject to the familialist paradigm that assigns women from modest backgrounds with little formal education to this almost exclusively feminine line of work. This study focuses more specifically on homebased childcare providers working in rural and suburban areas, spaces that are marked by isolation and a lack of interlocutors. There are many limitations to the occupation's professionalization model (Aballéa, 2005; Alberola, 2009). After providing an overview of the institutional norm of nursery school as it contrasts with the informal situation of home-based childcare, analysis shifts to three obstacles to expressing demand for training that are indices of low professionalization: the place and space of work, little social and familial arrangements, and work skills. Finally, in counterpoint, the article explores the role of the employment contract with parents in formalizing a feminine occupation that is still seen as a customary familial service (Dupraz, 2008).
\end{abstract}

\section{Keywords}

Gender, Education, Occupations, Early Childhood, Training, Home-Based Childcare Providers

\section{Introduction}

To this day, early childhood occupations in daycare, nursery school, and above all home-based childcare are marked by a lack of gender diversity. Childcare work is overwhelmingly performed by women, regulated by an agreement whose 
standards ${ }^{1}$ specify the occupation's content, hourly rates, and responsibility levels, all according to frameworks overseen by the health ministry's service for the protection of mothers and children. This historical supervision has emphasized care-related priorities from the beginning, establishing early childhood work in the care sector [1] [2], which is not without consequences on the naturalization of aptitudes as gendered abilities. The familialist paradigm thus assigns women to these jobs while thwarting the institutionalization of occupations in the sector by keeping a significant share of female childcare providers in the supply pool for preschool childcare.

The model for professionalizing this early-childhood occupation [3] [4] has many limitations, even encountering resistance from some childcare providers themselves, who are quite often among the most socially "fragile"2. Our study focuses on this social category, specifically those practicing in rural and suburban $^{3}$ areas, which are marked by isolation and the lack of interlocutors such as RAM (relais assistantes maternelles, centers providing support for home-based childcare providers) and outposts of the PMI (Protection maternelle et infantile; Mother and Child Protection Services), which are largely absent except for inspections. This applies in varying degrees to this professional group as a whole, however, subjected as it is to the uncertainty of an insecure occupation and the vulnerability of women. This uncertainty and insecurity are related to the facts of the lives of the people concerned [5] and the condition of vulnerability synthesizes these aspects [6] [7] as they were observed among home-based childcare providers, seen in their solitude, work space configurations, and status in the public and domestic spheres as well as their mobilization of the body at work [8].

Impediments to professionalization will be approached through the ways in which interviewees speak of how they relate to training. Indeed, we hypothesize that the formulation of requests for additional knowledge relies on social mechanisms that could act as so many obstacles, explaining the low demand for training observed in two recent surveys (one by CREDOC in 2009 and another by DREES in $\left.2013^{4}\right)$. Among these mechanisms, in addition to the previously mentioned indicators of vulnerability, particular attention will be given to gendered socialization and scholastic experience, which can contribute to a fraught relationship to knowledge [9]. Indeed, the sociology of education demonstrates close ties between family dispositions and attitudes toward school [10] that usually leads individuals with the lowest cultural and educational capitals to exclude themselves from explicitly requesting cultural goods and services from the outset. The article more specifically sets out to identify indirect formulations of

\footnotetext{
1"Référentiel de l'agrément des assistants maternels à l'usage des services de protection maternelle infantile", Edition DICOM, no. 09095, August 2009, page 15.

${ }^{2}$ CREDOC (Centre de Recherche pour l'Etude et l'Observation des Conditions de Vie), "La professionnalisation des assistants maternels: incidences de la loi portant sur la réforme du statut des assistants maternels", Cahier de recherche, no. 263, December 2009.

${ }^{3}$ See "Methods" box.

${ }^{4}$ DREES (Direction de la recherche, des études, de l'évaluation et des statistiques), Etudes et Résultats, no. 839, avril, 2013
} 
training needs, expressed distinctly from research participants' explicit rejection of the 120 hours of unanimously disliked mandatory training. To do so, analysis relies partly on observations of child supervision at nursery schools while children are arriving and departing. The objective was to gather data that shed light on mutual views of home-based childcare providers and the nursery school as an institution in order to reveal the latter's instituting effect on providers' relationship to training. In addition, the study included biographical interviews to gather life histories-providers' motivations, trajectories, opinions, lived experiences [11] [12]. Research participants' sociological profiles are in line with the occupation's main trends: women from working-class backgrounds, low educational attainments, married, an average of two children, began childcare work following maternity leave. Research was conducted in Normandy (France), a geographical area that the 2013 DREES report singled out as having an especially high recourse to childcare providers in rural areas. In Normandy, "two of five children under the age of three are watched by a home-based childcare provider", which is partly explained by the geographical distribution of families with young children, who are more often settled in rural areas: " $43 \%$ of families with a child under the age of three live in a rural town of under 2000 inhabitants, compared to an average of $25 \%$ of all families in mainland France". A statistical survey in 2008 placed Normandy among the regions of the northwest with a high supply of home-based childcare providers ${ }^{5}$. Moreover, Haute Normandy is in the average bracket for the schooling of two-year-old children, which implies that families call upon the services of childcare providers for the many instances where children only attend school in the morning.

After an overview of the institutional norm of nursery school and how it contrasts with the informal situation of home-based childcare, we will detail three obstacles to the expression of a demand for training, indicators of low professionalization: the work place and space, small social and familial arrangements, and job-related skills. Lastly, as a counterpoint, we will indicate the role played by the contract between providers and parents in the formalization of a feminine occupation that is still seen as falling under the status of a customary familial service [13].

\section{The Lack of Institutional Formalization}

In the field of early childhood, nursery school has long been a highly organized and normed institution, even more so than daycare. Its buildings, internal layout, and state or local civil-servant employees affirm the importance of its social function and the recognition of the professional expertise implemented there. These are all absent for home-based childcare providers, whose professionalism is borne exclusively by the double strollers around the school. At drop-off time, when they take their young charges to school, teachers and classroom assistants (ATSEMs) reduce them to their role of parental substitute.

${ }^{5}$ Tesson, C., Bideau, G., Besacier, M., Les assistantes maternelles en France en 2008: des accueils et des salaires variés, Politiques sociales et familiales, Synthèses et statistiques, no. 99, mars 2010. 
This social time is repeated two to four times a day following the cycle of the school day, and provides an occasion for observing home-based childcare providers' interest in the place and recording their exchanges with others dropping off or picking up children: "At the same time, it's normal-they can't keep their eyes on everything!" This is a way of asserting a shared experience among early childhood professionals. Such solidarity denotes an assertion of specific knowledge in their domain, although this knowledge does not cross the crucial line of formal educational qualifications and corresponds more to the tasks of classroom assistants than those of teachers. The ambivalence of their status can be read in the regard of teachers, who see home-based childcare providers as parents by delegation, while their interactions with classroom assistants are numerous and denote professional complicity.

Beyond common educational responsibilities and the fact that all are invariably women, classroom assistants and home-based childcare providers are also similar in place of residence, lifestyle, and biographical trajectory. Many years of mutual familiarity furthermore ensure continuity in school-family relations, since teachers are more mobile and change postings. Such familiarity can be seen in friendly greetings and clusters of adults discussing children outside the classrooms. They know how to get recognition for the knowledge they have acquired from teachers, and derive a certain pride from it: "Every child at his own pace ... You mustn't force him to hold a pencil. You just show them and it'll come!" Social class relations between hierarchically ranked women play out in this everyday dance. Home-based childcare providers return home, while classroom assistants cross to "the right side of the fence", at least as it is seen by those who once had or still entertain hopes of working as a classroom assistant. "I wanted to go back [to school] to do, um, to earn a $\mathrm{CAP}^{6}$ in Early Childhood Development, then, um ... So I thought, OK, I don't know where that'll take me, if I'll find [a job] in the area, if ... so that's that." Being part of the educational establishment procures a considerable legitimacy that home-based childcare providers lack.

The indefinite nature of their status weighs on them; poorly defined, between the domestic and public sphere, their situation obliterates recognition of their actual position in exchanges of services involving social life. But most of all, the insecurity of their activity from one year to the next contrasts sharply with the stability of institutions like the school, where regulation is collective, while home-based childcare providers face parents' disappointment or pique alone: "And that takes space. So I explain to the moms, when there's only one, one kid that goes to school part-time, no problem. I try to explain to them that there's probably a problem with the system, I just don't see how it can be solved. There's got to be a problem because we take care of kids up to when they start nursery school, yeah, that's it, and after, well, if we [childcare providers] only have kids that go to school, we don't work during the day anymore."

The contrast between the two systems is striking: "To do that at home where 
parents are, let's just say, pretty shameless [...] While in a nursery school I imagine that the rules are ... different." The obstacles related to their insecure situation also manifest in the concrete organization of their work as well as in the invisibility of their professional skills [14].

\section{The Domestic Space Where the Work Takes Place}

The first obstacle to formulating needs in training, a sign of a professional identity aware of its needs, is the place where young children are hosted: the family home. The domestic space and the intimacy of the private sphere are thus confused with the environment of professional practice. The simple material and symbolic division that is ordinarily demarcated in other occupations, practiced in dedicated spaces, does not exist for this occupation. It is therefore easy to understand all the difficulties that home-based childcare providers must overcome to avoid the pitfall of familiarity, as much for themselves as for the parent/employers: "And the disadvantages uh ... what could potentially be a burden is [hesitating] that [hesitating] that my job is done at home. [Pause] That I have to share my house, my children and all."

Isolation from staying in the home creates a routine and weakens motivations to think about one's practices. They lack an external view, exchanges with peers, and the controlling role played by a wider professional community, which in reality presupposes a non-negligible personal effort to break out of old work habits. Taking children into their homes requires a greater conscious effort than is called for in institutional settings like daycare or nursery school, where preexisting group conditions configure behavior from the outset. Group emulation is a decisive factor in reconsidering how work is done or the emergence of new needs for knowledge, but home-based providers do not work under those conditions, especially those who work in a rural or suburban area.

Often the feeling of being shut in and abandoned contrasts with the freedom experienced in a previous wage-earning job. The history of women's liberation is intimately connected to the opportunity to leave the house and housework in order to do paid work, and so one can appreciate how such a return to the home might seem like a regression, even when it is remunerated and appears to give renewed freedom in managing family time [15]. Women seem to find themselves once again ensnared by the trap pulling them back into the home. This solitude excludes them from any social and political life by confining them to the world of children within the home: "Mostly because I love children ... twice now I've said that I'm going to stop, and twice now I ultimately ... Ugh, I don't stop, basically. Ugh, I'm actually kind of fed up being at home." Complaints of feeling cut off from life and the discussions running through the working world inspire dreams of returning to wage labor: "The drawbacks I'd say, uh, are being isolated-very isolated, feeling alone-very often alone, not having the right to any visits with others. So actually I think there're a lot of drawbacks. To tell the truth, I'm currently getting other training, um, other than this one, and they're nice because we get together as colleagues, because we see people outside, adults! We 
see adults!"

The considerable time required and the availability it demands of the professional is far from the only challenge of the occupation, which also includes the inconvenience of the domestic space being occupied for a considerable period of the day. The $\mathrm{ONISEP}^{7}$ occupational description specifies the time span by recommending an $8 \mathrm{AM}$ to $7 \mathrm{PM}$ workday, under constant tension from being permanently alert: "At every moment the home-based childcare provider watches to avoid all risks and accidents. The home-based childcare provider introduces the children to the rules of living together. And participates in awakening their minds thanks to activities adapted to each age: games, painting, coloring, singing ..."

In the concrete everyday employer/employee relations between parents and childcare providers, the absence of a physical structure setting aside a specialized work space means that there is no material barrier marking the symbolic distance between the childcare provider as a social being and the social function she serves through her work. The requisite ethic toward children and parents is based on common sense without the explicit establishment of boundaries protecting intimacy and private life. The feeling of encroachment on or even invasion of private life is a clear expression of a need for professional training to better manage this problem in relations with parent-employers. The solutions to this challenge are experienced in the register of little arrangements and not seen as a kind of knowledge that can be shared; at best research participants mention looking for ways to counter the intrusion through discussions on social media. So although professionals do not formally express interest in getting control over this situation to supervisory authorities, its importance must not be overlooked, since the use of space is the first element in the recognition of social activities [16]. In sum, the place and space of their activity clearly signal their need for skills to manage this distinctive work situation.

\section{Little Family Arrangements}

The second obstacle to expressing a need for training comes from the strong legacy of a social structure that is segregated according to social class and gender relations assigning women to care tasks and the secondary position in the couple. Family life is structured by multiple constraints leading to choices being made according to gendered roles, causing women to be shut into the domestic space.

Interviewees' biographical accounts contain traces of the path of career change indicated in the CREDOC studies: the leading motivation for going into childcare work is past professional failure. These women's situations were changed by the birth of a second child, the constraints of their husband's job, or building a new house in the country. Many of the women in this study were rather good ${ }^{7}$ ONISEP: Office national d'information sur les enseignements et les professions, the governmental office for publication of information about education and career orientations (http://www.onisep.fr/). 
students in primary school, but started having problems in middle school. Their educational attainments include BTSs in secretarial work and tourism, a BEP in secretarial work, and a few vocational baccalauréats, and all began their working lives in the field of their initial training. ${ }^{8}$. All describe being guided to orientations other than the one in which they had initially expressed interest: a CAP or other degree in early childhood education. Ill informed and with little help from their families of modest means, they went along with the guidance orientations. Scenarios of job loss followed by career change are common, as in the case of one woman with a vocational baccalauréat degree in secretarial work who had to go to work at age 18 and was long an administrative assistant in a transportation company. Underprivileged women often see starting this new career as a second chance: "It can be advantageous for people without any degrees or other work. Yes, I think it's advantageous." The ideal of the stay-at-home mother is always invoked with the positive connotation of the benefits of raising one's own children and being available to them, without questioning the postulate. Indeed, these women commonly express satisfaction arising from the considerable consistency between the worlds of family and work and the lives they dreamed of as children: "Before, I worked in a business, in a castle and all that, and then I became a home-based childcare provider to be able to take care of my children." The model of the stay-at-home mother is thus deeply rooted in their representations, and the model of the wage-earning woman is limited to occupations with a feminine image that do not contradict the gendered job norms of childrearing and care. For instance, thinking back on her past career aspirations, one woman said her dream was "To take care of the children, actually, yeah! It was mostly schoolteacher, and then nurse when I was bigger." Another explained, "So I went to school, I got my baccalauréat, and it wasn't remotely what I wanted to do. Because I wanted more like studies in [hesitating], anyway my goal was to be a preschool teacher."

The life courses of research participants tell the story of strictly gendered socialization in large families where they learned to be "perfect little mothers" quite young, through imitation. They often described this investment as being total and experienced in the enchanted form of destiny: "When I was little, I'd play with dolls all the time, and I'd dream at night that my dolls turned into real babies. I swear it's the truth! That's how it was! And as soon as there was a baby ... I mean, I had an aunt who was a childcare provider, and when I'd go to her place during vacations, uh, I'd take care of the babies. Wherever there was a baby, like, I took care of the babies. It was ... so actually, I'd planned on this as a professional occupation, to go into early childhood education, in a setting ... I didn't plan on raising children at home, that's for sure."

School experience seems secondary in these accounts, and although the memories they report for primary school are generally positive, their prospects were ${ }^{8}$ BTS: brevet de technicien supérieur, a post-secondary vocational degree; BEP: brevet d'études professionnelles, a secondary-level vocational certificate; Baccalauréat: a competative examination marking the end of secondary-level education. 
cut short when they had to be oriented toward a more specialized educational track at the beginning of middle school. Analysis of the interviews revealed very short statements on the topic, while they were rich with examples, details, and anecdotes when talking about babies. This probably indicates a strategy of avoidance of the subject of school, denoting a fragile relationship with formal education. This lack of training in academic knowledge most likely engenders a lesser propensity for self-analysis and the elaboration of well-developed arguments for requesting training.

Maternity leave at the birth of a child is the crucial moment triggering the shift in these women's lives. They weight the costs and benefits of returning to their wage-earning jobs. The prospect of calling on the services of a home-based childcare provider for their own child sets off their new plan, which appears to be the best solution for the household. This thus reveals that the ensuing progression of steps is largely dictated by the needs of the family, especially the obstacles facing couples seeking care for their preschool-aged children. The experience of motherhood begins to resonate with a certain feminine upbringing during their own childhoods in which the role of mother seems to be quite salient. "It's a career change. I was a secretary, before, but I wanted to be a preschool teacher. But I didn't do it because I couldn't go to the school for early childhood education when I had the right age. And when I had my third son I took parental leave and then I decided to request my license [to care for children in her home] while I was on parental leave. Maybe the fact of getting used to a whole year of parental leave already, and then the second year came and I thought no, I won't go back. No, I couldn't see myself going back, uh ... leaving, uh ... and having three kids, too. I would have needed a childcare provider myself, for all three. And then, financially, too, to go to work, I worked in BoisGuillaume, my husband wasn't there during the week, it would've been complicated to get care for three kids, um, with working hours."

From this perspective, home-based childcare providers are traditional figures of gendered social relations and procure satisfaction from it. They like feeling perfectly in their place as women, between their roles of mother and child-raiser. They live in a feminine world where they feel comfortable in the home and around the nursery school where they meet mothers, grandmothers, and young women working as babysitters. By watching other people's children they even prolong their own motherhood and assert their social utility as women. The consistency of their place in society and at home is also based on the resources of their households, which settled in the suburbs or the country so they could afford a house. "So being at home when you live in the country, I think, it's pretty nice, too, when you've got a house, a yard-no doubt about it. Uh, there can also be financial advantages, because you should know that our incomes aren't taxable up to a certain level. There's no commuting costs, none of that. So financially I think that there're sitters who can make a really good living by working full time, uh-you can have 3 or 4 children. Well, I mean, that could ... that could [hesitating] be an advantage." 
An array of constraints weigh on these women's professional orientations, which they may experience as advantageous while still being subject to the many drawbacks of renewed conformity with the maternal role. Their house is simultaneously a little arrangement accepted as a lesser evil compared to the limitations of wage-earning jobs outside (and often far from) the home, and the actualization of an aspiration originating in their gendered childhood socialization. Their accounts make it evident that the couple's financial calculations won out in a context that is highly unfavorable to women's employment, given the limited geographical mobility possible for families of modest means. This reveals the considerable specificity of this home-based job, which from the outset limits efforts to obtain training by reinforcing the social model of the housewife. Immersed in this environment, it would be more difficult for these women to formulate their training needs or expectations without the intervention of very active public policy. At the same time, they frequently mention trying to get first-aid classes through nonprofit organizations.

\section{Invisible Child-Rearing Skills}

The third obstacle to formulating demands for training is integral to the fact that the technical knowledge of mothering is invisible. Whether it be the codification of the skills for caring for young children, knowledge of the legal framework for any and all interventions, or the linguistic prerequisites ensuring suitable language use for the children they mind, little has been genuinely formalized, and it is the informal setting of the job that primarily contravenes any vague desire for professionalization. Access to the profession is thought to be too easy, and home-based childcare providers themselves complain that licensing is not selective enough, reinforcing the lack of more demanding and better recognized training. As it stands, training is "a little too basic, uh, not administrative enough, not enough [hesitating] ... well, I think, uh, as a mom, I didn't learn much."

However, professional expertise is acquired through the patience necessary to relating to young children or in managing a small group with a range of ages, each with its own needs. "So you may well be a mom, you may well have kids, [but] you're not prepared to have three kids of the same age at the same time." There is specific training for these skills in order to be able to work in other early childhood occupations in daycare, nursery school, or recreational centers. Recognized as being one of trickiest aspects of pedagogy, these skills mark the boundary between professionalism and simple parenthood. The proximity of home-based childcare providers' work to their family activities explains the denial of the work their job entails, since domestic labor is a paradigmatic figure of invisible labor [17]. This further fuels parents' attitude ignoring the advice of their children's caregivers, who they consider unqualified and lacking an authoritative voice concerning childhood.

There are many challenges, including having to pay attention to the demands of very young children with limited and very individual means of expression and 
the stress of having to organize activities adapted to a significant age-range: "What's difficult when you're alone with several children, including a baby, is that with a baby, you never know when he'll wake up. So these days I don't do painting, things like that, because if he wakes up while we're in the middle of painting, you can't leave two two-year-olds all alone with the paint. So that's one thing. But for me, yeah, that's the training I think I need." These accounts are remarkable for revealing the awareness that theirs is an occupation that has to be learned and that there is nothing natural about the skills it requires, to the point of thinking about quitting when faced with the professional obstacles they have to overcome for lack of access to acquired knowledge for practicing the occupation. "Yes, where I could use training, yeah, it's in manual work, because I'm [hesitating] I'm not very, um, naturally gifted for that. I don't have spontaneous ideas of things to make." Summed up in a euphemized form by mentioning the patience required, the accounts demonstrate that it is actually a question of specific skills in decoding children's expectations and planning a string of very short activities at a sustained pace throughout the day. "I wouldn't have done it when I was younger-no question that when I was younger I wouldn't have had the patience."

Use of the body in this occupation also proves to be intense, through the noise, stress, constant availability, physical positions, and weight bearing, which may lead to musculoskeletal problems. Interviewees shared a number of pragmatic thoughts on the physical condition required of adults constantly responding to young children. Often unrecognized or even ignored because it is never quantified or taken into consideration, what interviewees refer to modestly as "energy" in fact describes the basis of all care occupations, most acknowledged among nurses [18]. Physical aptitude is put to use to carry loads and hold positions straining the body, such as leaning forward, bending down or squatting to put oneself at the level of a small child, picking children up to put them in a seat, and pushing strollers, so occupational risk prevention should devote more attention and training to the working person's body. The physical aspect of work is often overlooked, but it appears as soon as interviewees start thinking about their work in the long term. They rarely plan on continuing the job up to retirement age. Wear, tear, and the physical strain of the job are factors, alongside insecurity.

The fact that it is always predominantly a gendered body, the maternal body of women, fuels the conception of a simple transfer of natural aptitudes and impedes full awareness of the skills required to transpose activities from private life and individual experience into a professional environment [19] [20]. This work, which always presupposes the redefinition, adaptation, and transformation of knowledge and actions in professional situations [3], is experienced (but not described as such) in these biographical accounts. Here again are identifiable training needs that local authorities could act on without waiting for a demand to be formulated by the childcare professionals themselves. 


\section{The Contract as Counterpoint to a Little Formalized Occupation}

The signing of the contract between parent/employer and home-based childcare provider is the key moment of professional affirmation. All interviewee accounts indicate that it is the moment when their mastery of the administrative procedures for taking in young children establishes their authority with parents and formalizes their professional standing. The contract plays a decisive role countering the absence of any institutional manifestation, and this is undoubtedly why there is nearly unanimous demand for training on the subject. For some, secretarial experience in previous jobs made up for the lack of advice and preparation, but several referred to having used the resources available on union or association websites. "But maybe because I knew how to manage, though. Because on arrival, when I make the contract, I prepare the contract for you, I make the pay stub. Maybe the parents in front of me realize that they have someone who knows what she's talking about, and [hesitating] so, they can't say just anything. So yeah, the potential drawbacks ... they weren't too much for me because I was coming from a, um, administrative job so I knew, but the drawback is also that you find yourself alone in front of parents, uh, who don't know how to make an employment contract, who don't know how to make a pay stub, who don't know any of that. And here in the country, you know, nothing at all to advise us. I think in the city, um, sitters don't have these problems."

This point seems to be central, symbolically as well as legally. Indeed, the contract fulfills a statutory function equivalent to enrolment in a daycare center or an institution like nursery school. This is particularly tangible in the management of openings when the care provider has to refuse to keep minding a child when he or she reaches school age. Another facet of the contract refers to the relationship of subordination, which they experienced negatively in their previous occupations. They thus appreciate being self-employed for the freedom it ensures and the autonomy of their work free of the supervision of bosses and an oppressive hierarchy: "The license was easy. And at the same time I'm really happy at home because I kinda do what I want. Yeah! So the advantages for me, I'm independent, I'm all alone, I ... that's it, uh, I have the power to make decisions. So there, uh, I'm free!" Another told me, "We're independent in our work. You haven't got a boss on your back every day, as they say. And then, you, you're kinda free to manage your own time-with everyone else's schedules, which isn't always easy since we have multiple employers, but we manage well enough."

The faith and respect of parents do not procure social recognition, since they have trouble avoiding too much overlap in their roles: "Ultimately, yes, I feel respected but, uh, sometimes too much so. Sometimes a little too much the second mother for some of them, actually." Here, too, we catch a glimpse of an unformulated demand for more training: "[It also happens] with families that are in difficulty, sometimes. You end up playing the role of social worker, actually. You get overconfident, you try to set limits and focus on the child, to stay 
focused on the child [but] it's not always, uh, sometimes it's a bit too much and so it's a burden because I'm all alone dealing with them, actually. No one's supporting me to ... [trails off].”

Although signing the contract is an important act that establishes the value of mandate in the absence of a license ${ }^{9}$ [21], their job status nonetheless means that they are not required to pursue continuing education. Annual contracts are also insecure because home-based childcare depends heavily on the fluctuating demand of parents and childcare needs, which can furthermore dry up quickly in rural areas with low demographic renewal. Lastly, home-based childcare providers start their businesses with very limited means. "I don't think I'll do this job until I'm old enough to retire. Then on top of that it's a combination of circumstances, and we're all in about the same situation. We've got an insecure occupation. From one year to the next we don't know if all our openings will be taken. I'm going to look, yes indeed, to do something else. And my plan, still, would be to go back to my previous occupation, which is, uh, being an administrative assistant, but in a, um, association. I mean, to be an employee in an association mainly focused on children, that'd be my thing."

\section{Conclusions}

Among care work occupations, home-based childcare is subjected to a triple denial of professional skills: firstly because there are no relevant institutional supports organizations or they are far away; secondly because the place of professional practice is also the worker's private residence; and thirdly due to the limited prerequisites for eligibility for a professional license. They all combine to establish an image of childcare as a job not requiring any qualifications, an activity of pure biological reproduction arising from tradition and customary social function.

Representations of a "natural" activity that can be practiced by any woman, especially one having known motherhood, are thus reinforced. It is unsurprising, then, that it is a majority of married women with children who turn to the occupation while, inversely, it attracts very few men [22]. The first manifestation of this ideology is displayed in the very title of the occupation in French, assistante matérnelle ("maternal/mother's assistant"), which keeps the word "maternal" and thus assigns the job a feminine register in parental aid and support for the domestic reproductive function of the family. This lays the basis for defining the job on the fringes of more qualified care occupations such as nurse, nursery school teacher, and behavior therapist.

The study shows that home-based childcare providers still experience difficulties in overcoming the obstacles of the negative experience of education, isolation, working from home due to family arrangements, and the invisibility of professional skills, which all inhibit the demand for new knowledge. Their vul-

${ }^{9}$ Hugues, Chapoulie, (1996): “The permit designates an official authorization to practice an occupation and potentially the right for those possessing one to act outside the norms in force in society; the mandate concerns all duties formally assigned to a professional group" (http://archives.umc.edu.dz/). 
nerable condition shapes their relationship to an insecure occupation that is also heavily dependent on household stability. All interviewees encountered unfavorable conditions harmed their relationship to the occupation: working from home, no career development, revenue seen as a mere supplement to household resources, a lack of institutional framework, professional skills devalued by the naturalizing imagery of motherhood, and delicate face-to-face relations with parents. The particular situation of rural and suburban areas gives a good glimpse of the social class relations that distance modest households from urban centers. These households are thus led to reproduce gendered social relations through the wage-earning work of women who became home-based childcare providers so that their family could move into a house and so they could be present for their children. This conformity to the social norm of gender roles nourishes the partly illusory feeling reported by these women that they find their work fulfilling.

Reading between the lines of these workers' accounts reveals demands for training, and at a more exacting level than is usually offered. They often meet these needs by turning to social networks and association and union websites. All this moreover manifests a more than utilitarian need, since they all dreamed of being nursery school teachers and all seem to intend to fully accept their situation. Caught between specialized occupational skills that are nonetheless reduced to the level of everyday knowledge and the attention, concentration, and physical strain demanded by their work but whose importance is systematically minimized or denied, the profession as a group struggles to meet European-level educational ambitions. The vulnerability of their status opens many public policy perspectives for training, but the initiative is incumbent on public authorities, since these workers' sociological profiles, scholastic experiences, and working conditions prevent them from explicitly formulating their needs themselves.

\section{Conflicts of Interest}

The author declares no conflicts of interest regarding the publication of this paper.

\section{References}

[1] Hochschild, A. (1983) The Managed Heart: Commercialization of Human Feeling. University of California Press, Berkeley.

[2] Molinier, P. (2013) Le travail du care. La Dispute, Paris.

[3] Aballéa, F. (2005) La professionnalisation inachevée des assistantes maternelles. Recherches et Prévisions, 80, 55-65. https://doi.org/10.3406/caf.2005.2144

[4] Alberola, E. (2009) La professionnalisation des assistantes maternelles: Un processus en cours. Politiques Sociales et Familiales, 97, 71-76. https://doi.org/10.3406/caf.2009.2478

[5] Lianos, M., Bozatzis, N., Dobré, M. and Vicsek, L. (2005) Uncertainty and Insecurity in Europe (UIE). Final Report to the European Commission, Brussels.

[6] Castel, R. (2003) L'insécurité sociale: Qu'est-ce qu'être protégé? Seuil, Paris. 
[7] Castel, R. (2009) La montée des incertitudes: Travail, protections, statut de l'individu. Seuil, Paris.

[8] Angeloff, T. and Labourie-Racapé, A. (2004) Le travail du corps. Travail, Genre et Sociétés, 12, 29-31. https://doi.org/10.3917/tgs.012.0029

[9] Baudelot, C. and Establet, R. (2009) L'élitisme républicain. L'école française à l'épreuve des comparaisons internationals, Seuil, Paris.

[10] Lahire, B. (1995) Tableaux de familles. Heurs et malheurs scolaires en milieux populaires, Gallimard/Seuil, Paris.

[11] Demazière, D. (2003) Matériaux qualitatifs et perspective longitudinale. La temporalité des parcours professionnels saisis par les entretiens biographiques. Céreq Documents Séminaires, 171, 75-89.

[12] Demazière, D. and Gadéa, C. (2009) Sociologie des groupes professionnels. La Découverte, Paris.

[13] Dupraz, L. (2008) Nounou d'hier, assistante maternelle d'aujourd'hui: L'évolution d'une véritable profession. Spirale, 48, 57-73. https://doi.org/10.3917/spi.048.0057

[14] Benelli, N. and Modak, M. (2010) Analyser un objet invisible: Le travail de care. Revue française de sociologie, 5, 39-60. https://doi.org/10.3917/rfs.511.0039

[15] Méda, D. (2001) Le temps des femmes. Pour un nouveau partage des roles. Flammarion, Paris.

[16] Goffman, E. (1979) Gender Advertisements. Palgrave MacMillan, Basingstoke.

[17] Krinsky, J. and Simonet, M. (2012) Déni de travail: L'invisibilisation du travail aujourd'hui-Introduction. Sociétés Contemporaines, 87, 5-23. https://doi.org/10.3917/soco.087.0005

[18] Imbert, F., Kergoat, D., Le Doaré, H. and Sénotler, D. (1992) Les infirmières et leur coordination, 1988-1989. Éditions Lamarre, Paris.

[19] Mozère, L. (1998) Les métiers de la crèche: Entre compétences féminines et savoirs spécialisés. Y-a-t-il place pour une co-production? Cahiers du GEDISST, 22, 105-124.

[20] Mozère, L. and Jonas, I. (2011) On garde des vaches mais pas les enfants. Paroles d'auxilliaires de puériculture en crèche, ERES, Toulouse. https://doi.org/10.3917/eres.mozer.2011.01

[21] Hugues, E. (1996) Le regard sociologique: Essais choisis. EHESS, Paris.

[22] Pfefferkorn, R. (2007) Inégalités et rapports sociaux. Rapports de classes, rapports de sexes, La Dispute, Paris. 


\section{Box: Research Methods}

Research program Mixprim (Mixité dans les métiers de la prime enfance [Gender balance in early childhood occupations]), 2016-2019, IRIHS-GRR, RouenNormandie Université, Sophie Devineau (program director).

Preliminary studies of home-based childcare providers and their social position in interactions with school, taking two approaches:

- Observation in a nursery school in the French department of Basse Normandie in 2003 (prolonged immersion) and again in 2014 and 2015 (periodic observations). Research on school/family relations with field notes taken outside classrooms and at the school gate while children were being dropped off and picked up. Study of verbal, spatial, and corporeal interactions: exchanges, topography, gestures. Study of the socio-demographic profiles and life histories of classroom assistants. Research conducted by S. Devineau.

- Research through biographical interviews of ten home-based childcare providers in a rural area of the French department of Haute Normandie in 20152016. Study of socio-demographic profiles and life histories. Research conducted by Marine Barriuso for her Master 2 in Early Childhood, advisor Sophie Devineau; analysis and publication by S. Devineau.

\begin{tabular}{|c|c|c|c|c|c|c|c|c|}
\hline Interviewee & Age & Married & Children & Mother's PCS ${ }^{*}$ & Father's PCS & Education & $\begin{array}{l}\text { Previous } \\
\text { occupation }\end{array}$ & $\begin{array}{l}\text { Date license* } \\
\text { received }\end{array}$ \\
\hline 1 & 37 & Yes & 2 & House cleaner & Disabled & $\begin{array}{l}\text { Dropped out in first year } \\
\text { of high school }\end{array}$ & Dog handler & 2009 \\
\hline 2 & 30 & Yes & 2 & $\begin{array}{l}\text { Home-based } \\
\text { childcare provider }\end{array}$ & $\begin{array}{l}\text { Electrical } \\
\text { engineer }\end{array}$ & Secretarial studies & Secretary & 2009 \\
\hline 3 & 46 & Yes & 3 & Florist & Florist & $\mathrm{BTS}^{*}$, tourism & $\begin{array}{l}\text { Salesperson } \\
\text { Housewife }\end{array}$ & 2009 \\
\hline 4 & 51 & Yes & 3 & Salesperson & Woodworker & $\begin{array}{l}\text { Bac Pro }{ }^{\star} \text {, } \\
\text { secretarial work }\end{array}$ & $\begin{array}{l}\text { Executive assistant } \\
\text { Unemployed }\end{array}$ & 2003 \\
\hline 5 & 37 & Yes & 3 & Housewife & Transporter & Baccalauréat ${ }^{*}$ & Restaurant work & 2008 \\
\hline 6 & - & Yes & 4 & Housewife & Worker & $\begin{array}{l}\text { Dropped out at the } \\
\text { end of middle school }\end{array}$ & Employee in a shop & 1999 \\
\hline 7 & 43 & Yes & 2 & Housewife & Roofer & $\begin{array}{l}\text { Bac Pro*, sales and } \\
\text { service }\end{array}$ & - & 1997 \\
\hline 8 & 28 & Yes & 2 & "Babysitter" & - & Bac Pro $^{*}$, accounting & - & 2007 \\
\hline 9 & 51 & Yes & 4 & Housewife & Civil servant & Baccalauréat & - & 1998 \\
\hline 10 & 41 & Yes & 3 & Housewife & Dock hand & $\mathrm{BEP}^{\star}$, secretarial studies & Secretary & 2006 \\
\hline
\end{tabular}

${ }^{*}$ PCS: Profession et catégorie socioprofessionnelles (profession and socio-professional category), the nomenclature for occupations used by INSEE (National Institute of Statistics and Economic Studies). ${ }^{*}$ BTS: Brevet de technicien supérieur, and advanced technical degree representing two years of study after having earned the baccalauréat. ${ }^{\star}$ Bac pro: baccalauréat professionnel (vocational baccalauréat). ${ }^{*}$ Baccalauréat: A rigorous nationwide examination capping secondary-level studies and granting access to university. ${ }^{\star} \mathrm{BEP}$ : brevet d’ études professionnelles (a secondary-level vocational certificate). ${ }^{\star}$ License: Legal authorization to care for other people's children in one's home, granted by the General Council of the administrative department where the activity is to take place in conjunction with the departmental branch of Mother and Child Protection Services (PMI, Protection maternelle et infantile). 